Article

\title{
Synthesis and Biological Activities on Metal Complexes of 2,5-Diamino-1,3,4-thiadiazole Derived from Semicarbazide Hydrochloride
}

\author{
Joshua A. Obaleye ${ }^{1}$, Johnson F. Adediji ${ }^{2, *}$ and Matthew A. Adebayo ${ }^{2}$ \\ 1 Department of Chemistry, University of Ilorin, Ilorin, Kwara State, Nigeria; \\ E-Mail: jobaleye@yahoo.com; Tel.: +2348033582048 \\ 2 Department of Chemical Sciences, Ajayi Crowther University, Oyo State, Nigeria \\ * Author to whom correspondence should be addressed; E-Mail: dijijohnson@yahoo.com; \\ Tel.: +2348035720485 .
}

Received: 30 April 2010; in revised form: 27 June 2011 / Accepted: 6 July 2011 /

Published: 12 July 2011

\begin{abstract}
A bioactive ligand, 2,5-diamino-1,3,4-thiadiazole (L), derived from semicarbazide hydrochloride, and its metal complexes were prepared and characterized. The complexes were characterized using elemental, infra-red, ultraviolet/visible, magnetic moment, atomic absorption, thin layer chromatography and molar conductance measurements. The IR data revealed that the ligand $(\mathbf{L})$ behaved as a tridentate neutral ligand. It coordinated to the metal ion via sulphur and nitrogen of the amines. The molar conductance data reveal that the chelates are non-electrolytes. From the Ultraviolet/Visible spectra and magnetic moment data, the complexes were found to have octahedral geometrical structure. In vivo evaluation of the antimicrobial activities of the metal complexes and the ligands showed greater activity against some micro-organisms when compared to the parent compounds. The chelates do not show toxicity against the activities of enzymes from homogenates of liver, kidney and serum in experimental rats.
\end{abstract}

Keywords: antimicrobial; toxicological; semicarbazide hydrochloride; ligand 


\section{Introduction}

Aminourea based derivatives exhibit a range of bioactivities, including anti-angiogenic, anti-tumour, anti-malarial, anti-inflammatory and analgesic [1-3], anti-tubercular, anti-glaucoma, anti-HIV, cytotoxic and antimicrobial properties [4-6].

The synthesis of metal aminourea derivatives had received much attention due to the fact that they are among the first effective chemotherapeutic agents to be employed for the prevention and cure of bacterial infection in humans. The pharmacological activity of these types of molecules is often enhanced by complexation with metal ions $[7,8]$. The antibacterial activity of aminourea is confined only to micro-organisms which synthesize their own folic acid [9]. The effectiveness of burn treatment seemed to depend not only on the presence of metal ions but also crucially on the nature of the material to which the metal ion is bound [10]. Certain theories had been advanced advocating that a major portion of drug action occurred through complexation [11].

The importance of metal ions in biological systems is well known. One of the most interesting features of metal coordinated systems is the concerted spatial arrangement of the ligands around the metal ion. Among metal ions of biological importance, $\mathrm{Cu}$ (II) ion presents a high number of complexes with distortion [12].

In recent years, several aminourea derivatives have been synthesized and their biological activities have been explored [13], but few experimental data about their antimicrobial and toxicological activities have been reported. The present study sought to investigate the physicochemical and biological activities of some novel aminourea derivatives. In continuation of our work on biologically important ligand metal complexes [14,15], this work therefore involves the synthesis, characterization and biological studies of $\mathrm{Co}(\mathrm{II}), \mathrm{Ni}(\mathrm{II})$ and $\mathrm{Cu}(\mathrm{II})$ complexes with 2,5-diamino-1,3,4-thiadiazole.

\section{Results and Discussion}

\subsection{Preparation and Characterization of the Ligand}

The cyclisation of bithiourea was performed by $3 \%$ hydrogen peroxide $\left(\mathrm{H}_{2} \mathrm{O}_{2}\right)$. The probable mechanism of this cyclisation is shown in Scheme 1 below. Compound $\mathbf{L}$ was separated in high yield (96.4\%). The structure of the ligand $\mathbf{L}$ was elucidated based on elemental (Table 1) and spectral data. Its IR spectra (Table 2) showed the absorption bands of $\mathrm{NH}_{2}$ and $\mathrm{C}-\mathrm{S}$ at 3,195 and $1,430 \mathrm{~cm}^{-1}$, respectively.

The aim of this study was to investigate the chelating properties of the 2,5-diamino-1,3,4thiadiazole ligand towards some biologically important metals like $\mathrm{Co}(\mathrm{II}), \mathrm{Ni}(\mathrm{II})$ and $\mathrm{Cu}(\mathrm{II})$ and assign the possible structures of these complexes. The results of the elemental analyses $(\mathrm{C}, \mathrm{H}, \mathrm{N}, \mathrm{S}$ and metal content) with the proposed molecular formulae are presented in Table 1. The results obtained are in good agreement with those calculated for the suggested formulae, 1:2 (M:L) solid chelates are isolated and found to have the general formulae $\left[\left(\mathrm{ML}_{2}\right)\right] \mathrm{X}_{2} ; \mathrm{M}=\mathrm{Co}(\mathrm{II}), \mathrm{Ni}(\mathrm{II})$ and $\mathrm{Cu}(\mathrm{II})(\mathrm{X}=\mathrm{Cl})$. The solid complexes are prepared and characterized by different tools of analyses like IR, molar conductance, magnetic moment, UV/Visible (Table 3) and atomic absorption spectroscopy to throw more light on the coordination behaviour of this ligand towards some biologically active metals under study. 
Scheme 1. Mechanism for cyclisation of bithiourea.

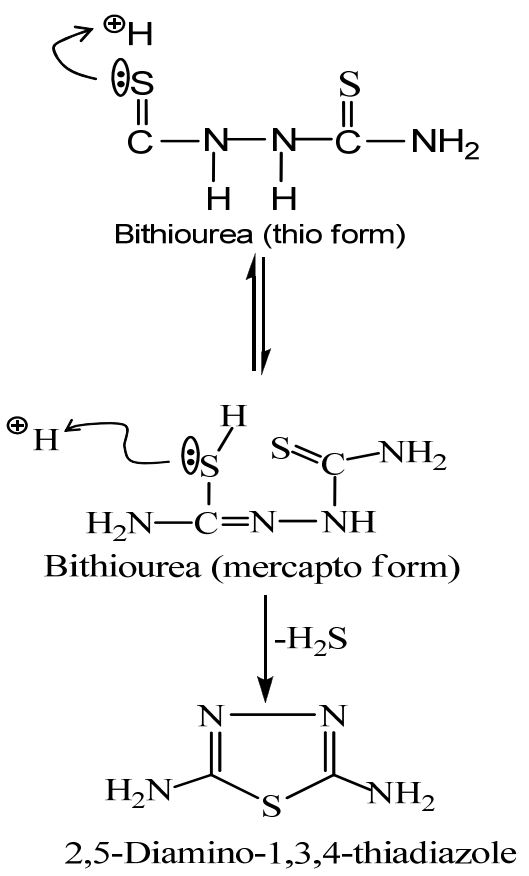

Table 1. Magnetic moment and elemental data of Ligand and their metal complexes.

\begin{tabular}{|c|c|c|c|c|c|c|c|c|}
\hline \multirow{2}{*}{ Compound } & \multirow{2}{*}{$\begin{array}{c}\text { Empirical } \\
\text { formula }\end{array}$} & \multirow{2}{*}{$\begin{array}{c}\text { Formula } \\
\text { weight }\end{array}$} & \multirow{2}{*}{$\begin{array}{c}\mu_{\text {eff }} \\
(\mathbf{B M})\end{array}$} & \multicolumn{5}{|c|}{ Elemental Analysis Calculated (Found) } \\
\hline & & & & $\mathbf{C}$ & $\mathbf{H}$ & $\mathbf{N}$ & $\mathbf{S}$ & Me \\
\hline $\mathbf{L}$ & $\mathrm{C}_{2} \mathrm{H}_{4} \mathrm{~N}_{4} \mathrm{~S}$ & 116.00 & - & $\begin{array}{c}20.69 \\
(20.67)\end{array}$ & $\begin{array}{c}3.45 \\
(3.42)\end{array}$ & $\begin{array}{c}48.28 \\
(48.22)\end{array}$ & $\begin{array}{c}13.79 \\
(13.73)\end{array}$ & - \\
\hline $\mathrm{Co}(\mathrm{L})_{2} \mathrm{Cl}_{2}$ & $\mathrm{CoC}_{4} \mathrm{H}_{8} \mathrm{~S}_{2} \mathrm{Cl}_{2}$ & 361.50 & 4.72 & $\begin{array}{c}13.28 \\
(13.24)\end{array}$ & $\begin{array}{c}2.21 \\
(2.20)\end{array}$ & $\begin{array}{c}30.98 \\
(30.97)\end{array}$ & $\begin{array}{c}17.22 \\
(17.20)\end{array}$ & $\begin{array}{c}16.04 \\
(16.00)\end{array}$ \\
\hline $\mathrm{Ni}(\mathrm{L})_{2} \mathrm{Cl}_{2}$ & $\mathrm{NiC}_{4} \mathrm{H}_{8} \mathrm{~S}_{2} \mathrm{Cl}_{2}$ & 361.00 & 4.26 & $\begin{array}{c}13.30 \\
(13.29)\end{array}$ & $\begin{array}{c}2.22 \\
(2.21)\end{array}$ & $\begin{array}{c}31.02 \\
(31.01)\end{array}$ & $\begin{array}{c}17.73 \\
(17.70)\end{array}$ & $\begin{array}{c}16.07 \\
(16.02)\end{array}$ \\
\hline $\mathrm{Cu}(\mathrm{L})_{2} \mathrm{Cl}_{2}$ & $\mathrm{CuC}_{4} \mathrm{H}_{8} \mathrm{~S}_{2} \mathrm{Cl}_{2}$ & 367.00 & 1.90 & $\begin{array}{c}13.08 \\
(13.04)\end{array}$ & $\begin{array}{c}2.18 \\
(2.15)\end{array}$ & $\begin{array}{c}30.52 \\
(30.50) \\
\end{array}$ & $\begin{array}{c}17.44 \\
(17.40)\end{array}$ & $\begin{array}{c}17.44 \\
(17.40)\end{array}$ \\
\hline
\end{tabular}

Table 2. IR spectral assignment of $\mathrm{L}$ and its metal complexes.

\begin{tabular}{|c|c|c|c|}
\hline Ligand/complexes & $\boldsymbol{v}\left(\mathbf{N H}_{2}\right)$ & $\boldsymbol{v}(\mathbf{C}-\mathbf{S}) \mathbf{c m}^{-\mathbf{1}}$ & $\boldsymbol{\Delta}\left(\mathbf{N H}_{\mathbf{2}}\right) \mathbf{c m}^{\mathbf{- 1}}$ \\
\hline $\mathbf{L}$ & $3195.31, \mathrm{~b}$ & 1430, str. & $1536.55, \mathrm{str}$. \\
$\mathbf{C o}(\mathbf{L})_{\mathbf{2}} \mathbf{C l}_{\mathbf{2}}$ & $3414.06, \mathrm{~b}$ & $1429.98, \mathrm{~s}$ & $1536.92, \mathrm{~s}$ \\
$\mathbf{N i}(\mathbf{L})_{\mathbf{2}} \mathbf{C l}_{\mathbf{2}}$ & $3414.48, \mathrm{~b}$ & $1429.82, \mathrm{~s}$ & $1537.62, \mathrm{~s}$ \\
$\mathbf{C u}(\mathbf{D T})_{\mathbf{2}} \mathbf{C l}_{\mathbf{2}}$ & $3424.82, \mathrm{~b}$ & $1407.37, \mathrm{~s}$ & \\
\hline
\end{tabular}

Table 3. Ultraviolet/visible spectral assignment of $\mathrm{L}$ and its metal complexes [wavelength, $\mathrm{nm}\left(\mathrm{cm}^{-1}\right)$ ].

\begin{tabular}{|c|c|c|c|c|}
\hline Compound & Band 1 & Band 2 & Band 3 & Band 4 \\
\hline $\mathbf{L}$ & $205(48780)$ & $238(42017)$ & - & - \\
$\mathbf{C o}(\mathbf{L})_{2} \mathbf{C l}_{2}$ & $232(43103)$ & $271(36900)$ & $526(19011)$ & $529(18904)$ \\
$\mathbf{N i}(\mathbf{L})_{2} \mathbf{C l}_{2}$ & $229(43668)$ & $256(39063)$ & $343(29155)$ & $817(12240)$ \\
$\mathbf{C u}(\mathbf{L})_{2} \mathbf{C l}_{2}$ & $229(43668)$ & $277(36101)$ & $361(27700)$ & $364(27473)$ \\
\hline
\end{tabular}


The metal chloride salts react with the ligand $\mathbf{L}(\mathbf{L}=2,5$-diamino-1,3,5-thiadiazole $)$ according to the following proposed general equation: $\left[\mathrm{M}(\mathrm{II}) \mathrm{L}_{2}\right] \mathrm{Cl}_{2}$, where $\mathrm{M}=\mathrm{Cu}^{2+}, \mathrm{Co}^{2+}$ and $\mathrm{Ni}^{2+}$ metal salt. The complexes synthesized were found to be non-hygroscopic solids with light green, peach and green colours, respectively (Table 4). The complexes are well soluble in DMSO and DMF and hot distilled water. They have sharp melting points, and no decomposition was observed. The average percentage yield was very high. The retention factor $\left(\mathrm{R}_{\mathrm{f}}\right)$ values was calculated from the developed single spot for the complexes indicating the purity of the compound [16]. The retention factor of the metal complexes was found to be higher than the ligand. The analytical data of the metal complexes showed 1:2 stoichiometry.

Table 4. Physical properties of $\mathrm{L}$ and its metal complexes.

\begin{tabular}{|c|c|c|c|c|}
\hline Compounds & $\begin{array}{c}\text { Melting } \\
\text { point }\left({ }^{\circ} \mathbf{C}\right)\end{array}$ & Colour & \% Yield & $\begin{array}{c}\text { Conductivity } \\
\left(\mathbf{\Omega}^{-\mathbf{1}} \mathbf{c m}^{-\mathbf{1}} \mathbf{d m}^{-\mathbf{3}}\right)\end{array}$ \\
\hline $\mathbf{L}$ & 208 & White & 96.4 & \\
$\mathbf{C o}(\mathbf{L})_{\mathbf{2}} \mathbf{C l}_{\mathbf{2}}$ & 190 & Peach & 75.2 & $1.7 \times 10^{-6}$ \\
$\mathbf{N i}(\mathbf{L})_{2} \mathbf{C l}_{2}$ & 200 & Green & 61.3 & $1.3 \times 10^{-6}$ \\
$\mathbf{C u}(\mathbf{L})_{\mathbf{2}} \mathbf{C l}_{\mathbf{2}}$ & 140 & Light green & 87.3 & $2.4 \times 10^{-6}$ \\
\hline
\end{tabular}

\subsection{Infrared Spectra and Mode of Bonding}

The IR spectra of the free ligand and their metal complexes were recorded in the range of $4,000-400 \mathrm{~cm}^{-1}$ and are listed in Table 2. The assignments have been carried out based on literature values obtained for structurally similar compounds [21]. The important IR frequencies of the ligand $\mathbf{L}$ and the metal complexes (in $\mathrm{KBr}$ ) with their tentative assignments are given. Both the free ligand and the metal complexes are characterized by $v(\mathrm{~N}-\mathrm{H}), \delta\left(\mathrm{NH}_{2}\right), v(\mathrm{C}-\mathrm{S})$ bands [22]. The absorption patterns look quite similar to that of the free ligand which is in agreement with coordination through nitrogen atom. The band around 3,400-3,100 $\mathrm{cm}^{-1}$ is assigned to $v(\mathrm{NH})$ and is supported by the presence of $\delta\left(\mathrm{NH}_{2}\right)$ deformation bands around $1,600-1,500 \mathrm{~cm}^{-1}$. A blue shift was observed in the v(C-S) frequency of the complexes, in comparison to the free ligand, which indicates coordination through the sulphur atom. Bands between $800-900 \mathrm{~cm}^{-1}$ which were absent in the free ligand, are assigned to M-L and are due to the metal-ligand coordination. Using the IR spectra, it is concluded that the ligand $\mathbf{L}$ behaves as a neutral tridentate ligand. It coordinated to the metal ions via the nitrogen of the amines and sulphur atom.

\subsection{Molar Conductance Data}

The molar conductance of the solid complexes $\left(\lambda_{\mathrm{m}}, \Omega^{-1} \mathrm{~cm}^{2} \mathrm{~mol}^{-1}\right)$ was calculated. The DMF solubility of the above complexes made calculations of the molar conductivity $\left(\lambda_{\mathrm{m}}\right)$ of $10^{-3} \mathrm{~mol} \mathrm{dm}^{-3}$ solution at $25{ }^{\circ} \mathrm{C}$ possible. The data in Table 4 showed that the molar conductance values of the $\mathrm{Co}(\mathrm{II}), \mathrm{Ni}(\mathrm{II})$, and $\mathrm{Cu}(\mathrm{II})$ complexes were relatively low, indicating the non-electrolytic nature of these complexes. 


\subsection{UV/Visible Spectra and Magnetic Moments}

For the Co(II) complex with ligand $\mathbf{L}$ the UV/visible spectra showed two bands in the visible region at $19,011 \mathrm{~cm}^{-1}$ and $18,904 \mathrm{~cm}^{-1}$, which were assigned to ${ }^{4} \mathrm{~T}_{1 \mathrm{~g}}(\mathrm{~F}) \rightarrow{ }^{4} \mathrm{~T}_{2 \mathrm{~g}}(\mathrm{~F})$ and ${ }^{4} \mathrm{~T}_{1 \mathrm{~g}}(\mathrm{~F}) \rightarrow{ }^{4} \mathrm{E}_{2 \mathrm{~g}}(\mathrm{~F})$ transitions, respectively, which assume an octahedral geometry for Co(II) complex [25-27]. The two bands at 43,103 and 36,900 $\mathrm{cm}^{-1}$ refer to LMCT [24]. The Co(II) complex had $\mu_{\text {eff }}$ of 4.69-4.92 BM which assumed a high spin octahedral geometry [23], that may arise from spin-spin coupling and/or crystal distortion.

The electronic spectra of the Ni(II) complex of the 2,5-diamino-1,3,4-thiadiazole ligand displays one band in the visible region at $12,240 \mathrm{~cm}^{-1}$ which is assigned to ${ }^{3} \mathrm{~A}_{2 \mathrm{~g}} \rightarrow{ }^{3} \mathrm{~T}_{2 \mathrm{~g}}$. The bands at $43,668 \mathrm{~cm}^{-1}, 39,063 \mathrm{~cm}^{-1}$ and $29,155 \mathrm{~cm}^{-1}$ refers to LMCT [24]. This indicates the octahedral geometry of the $\mathrm{Ni}(\mathrm{II})$ complex [23]. The $\mathrm{Ni}(\mathrm{II})$ complex has $\mu_{\mathrm{eff}}$ of 3.53-4.26 BM, which suggest an octahedral geometry.

The UV/visible of the $\mathrm{Cu}(\mathrm{II})$ complex consists of a broad and low intensity shoulder band at $27,473-43,668 \mathrm{~cm}^{-1}$ that forms part of the charge transfer band. The ${ }^{2} \mathrm{E}_{\mathrm{g}}$ and ${ }^{2} \mathrm{~T}_{2 \mathrm{~g}}$ states of the octahedral $\mathrm{Cu}(\mathrm{II})$ ion $\left(\mathrm{d}^{9}\right)$ split under the influence of the tetragonal distortion into three transitions and remain unresolved in the spectra. It is concluded that all three transitions lie within the single broad envelope centred at the same range previously mentioned. This assignment is in agreement with the general observation that $\mathrm{Cu}(\mathrm{II}) \mathrm{d}$-d transitions are normally close in energy. The $\mathrm{Cu}(\mathrm{II})$ complex has $\mu_{\text {eff }}$ of 1.83-1.96 BM, assuming a distorted octahedral structure [24].

\subsection{Structural Interpretation}

Consequently, the structures proposed are based on octahedral geometric structures. The 2,5-diamino-1,3,4-thiadiazole coordinate via nitrogen of the amines and sulphur atom forming three binding chelating sites. Figures 1-3 reported the antimicrobial activity results determined from the in-vitro studies of the ligand and its metal complexes. Generally, the ligand and metal complexes showed antimicrobial effect against the tested organisms, except against moulds of penicillin and Aspergillius as presented in the figures above. Niesseria gonorrhoea was the most sensitive organism to the 2,5-diamino-1,3,4-thiadizole and its metal complexes. Metal complexes showed comparable or greater activity against some of the micro-organisms in comparison to the parent compounds.

The MIC of the samples against the various isolates ranged from $15 \mu \mathrm{g} / \mathrm{mL}$ to $700 \mu \mathrm{g} / \mathrm{mL}$. These concentrations in comparison to the reported $\mathrm{MIC}_{90}$ of the ligand elsewhere are very high. This could be due to the different conditions under which the studies were carried out. These are reflections of the fact of possible interference from the media broth and some other materials and chemicals used during the test, which are not absolutely compatible with conditions present in the cells [27].

For a particular antimicrobial, the organism involved is an important factor; Salmonella typhi, Shigella species, Pseudomonas aeruginosa are more sensitive to the metal complexes than Klebsiella species, Escherichia coli and Staphylococcus aureus. Reports have shown that $\mathrm{CuCl}_{2} \cdot 2 \mathrm{H}_{2} \mathrm{O}$, $\mathrm{CoCl}_{2} \cdot 6 \mathrm{H}_{2} \mathrm{O}$ and $\mathrm{NiCl}_{2} \cdot 6 \mathrm{H}_{2} \mathrm{O}$ have no inhibitory activity on bacteria and fungi species [21]. 
Figure 1. Sensitivity test of the ligand and metal complexes against some micro-organisms.

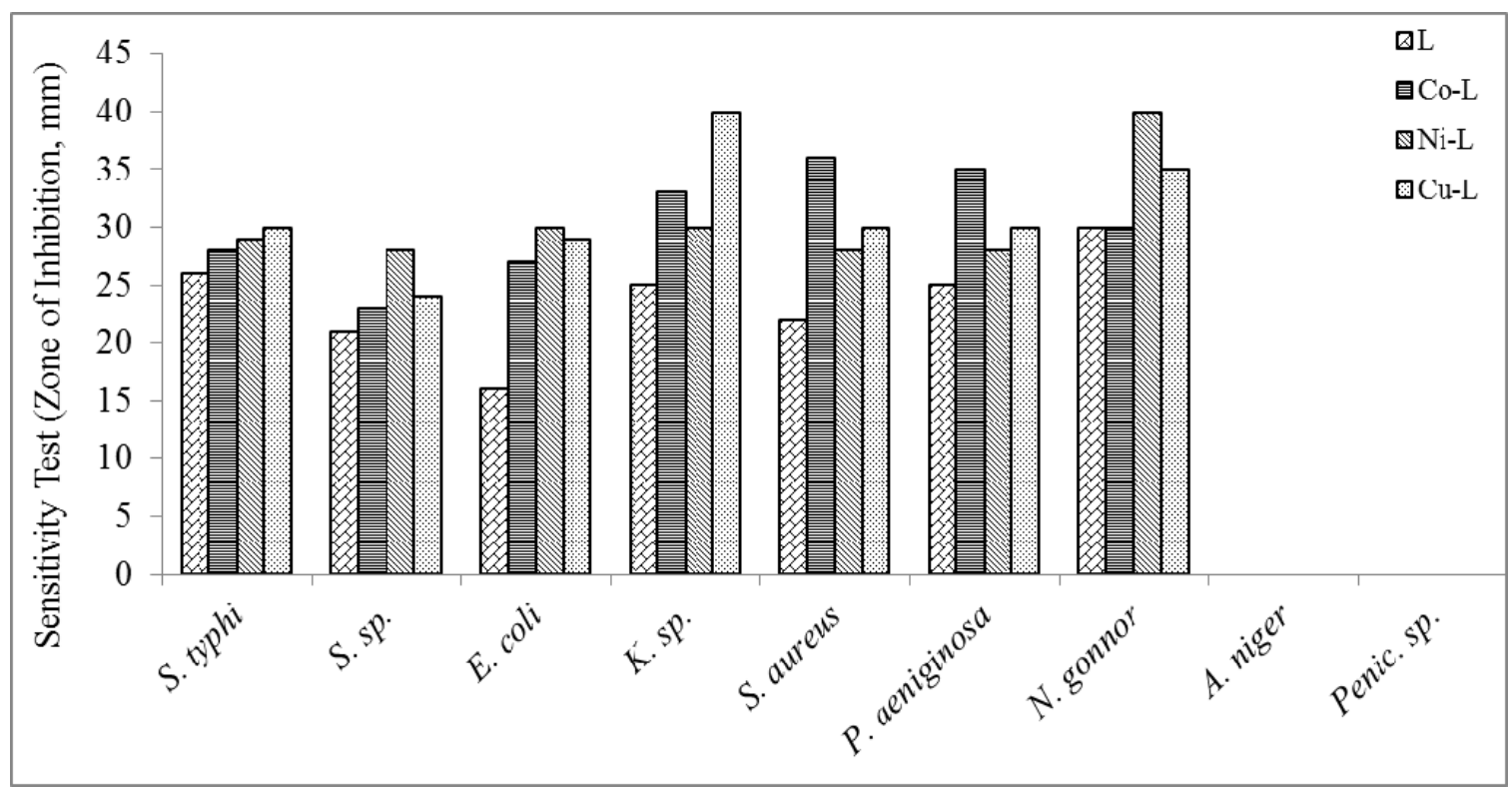

Key: S.typhi = Salmonella typhi, S.sp = Shigella species, E.coli $=$ Echerichia coli, K.sp $=$ Klebsiella species, S.aureus = Staphylococcus aureus, P.aeru = Pseudomonas aeruginosa, N.gonnorrhoea $=$ Niesseria gonorrhoea .

Figure 2. Minimum inhibition concentration of the ligand and metal complexes against some micro-organisms.




Figure 3. Minimum bactericidal concentration of the ligand and metal complexes against some micro-organisms.

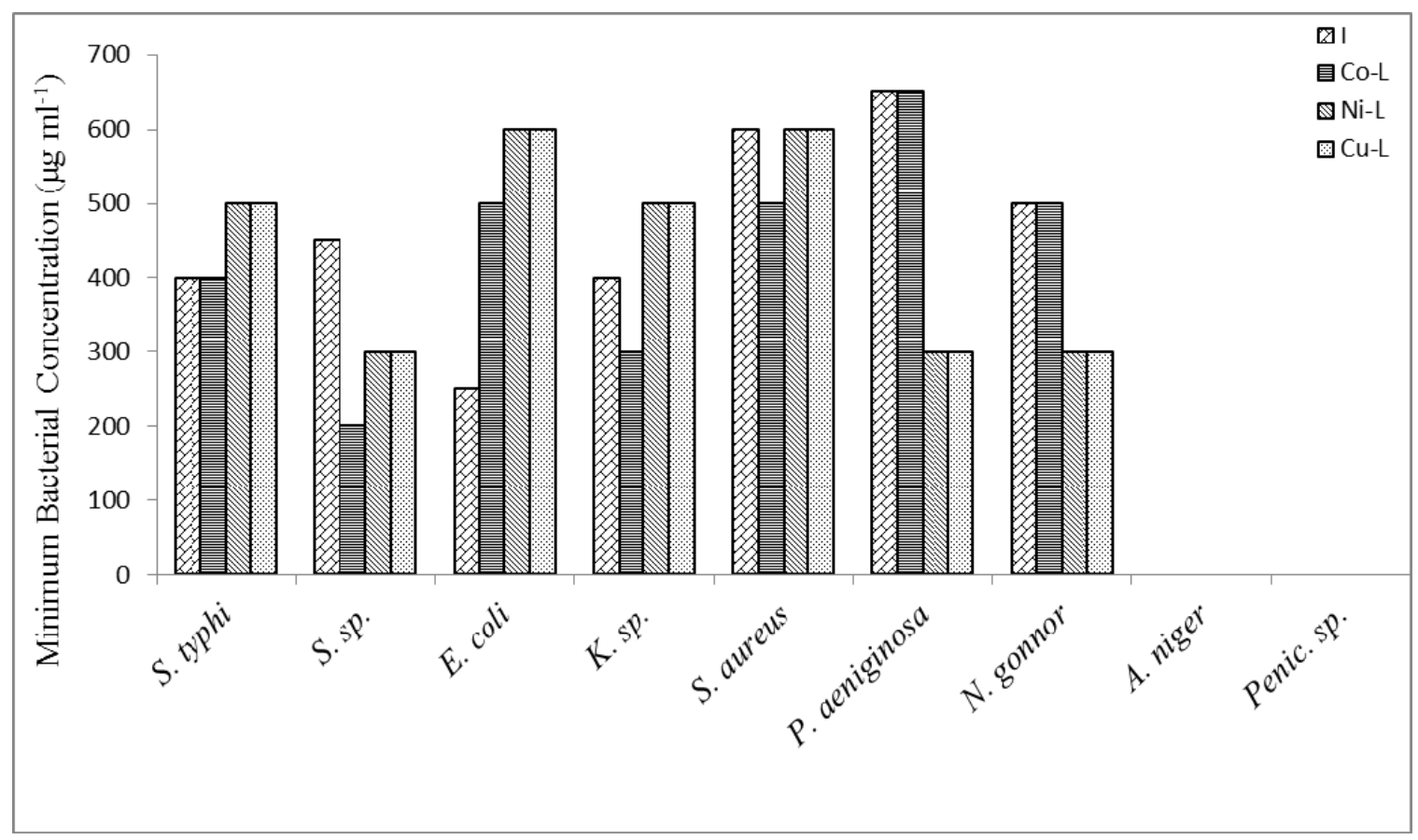

Figures 4-6 show the results of ALP, ALT and AST activities in the serum, kidney and liver. There was no significant reduction $(\mathrm{p}<0.05)$ in serum ALP activities of 2,5-diamino-1,3,4-thiadiazole and its metal complex compared with control, this suggests that the integrity of the plasma membrane of the cells in the various tissues might have not been adversely affected. This is because ALP is a membrane-bond enzyme often used to assess the integrity of the plasma membrane and endoplasmic reticulum [29]. The observed significant increase in the ALP activities in the liver and kidney of the rat administered with metal complexes suggests an enhancement of the activities of the existing enzymes by the drugs and their metabolites. The increase may be as a result of stress imposed on the tissue by the drug, which may lead to loss of the enzyme molecule through leakage into the extra-cellular fluid, which has been significantly noticed in the serum. In a bid to offset this stress, the tissue may increase the de novo synthesis of the enzyme, thus accounting for the increase in activities in these tissues [30]. However the metal complex of $\mathrm{Cu}$ (II) caused a significant increase in serum ALT activity compared with control. There was also a significant increase in liver and kidney ALT and AST activities compared with control. Elevation of serum ALT and AST activity is a pointer to leakage from a damaged tissue. Increase in serum ALT and AST has been reported in conditions involving necrosis of hepatocytes [30], myocardial cells, erythrocyte and skeletal muscle cells [31]. Overall, the integrity of the cell membranes of the various tissues (especially kidney and liver) was not adversely affected by the metal complexes. It is established from combined results of the chemical and physical analysis and from previous reports that the ligand (2,5-diamino-1,3,4-thiadiazole) employed in this work coordinated with $\mathrm{Co}(\mathrm{II}), \mathrm{Ni}(\mathrm{II})$ and $\mathrm{Cu}(\mathrm{II})$. The metal complexes possess better physical properties than the parent compound. The toxicological studies revealed that the metal complexes are not toxic at the dosage level administered. Based on various activities observed, metal complexes of 2,5-diamino1,3,4-thiadiazole would be a better therapeutic drug for antibacterial treatment. 
Figure 4. Effect of administration of ligand and the metal complex on the activities of alkaline phosphatase of rat serum, kidney and liver. * Significantly different from the control $(\mathrm{p}<0.05)$.

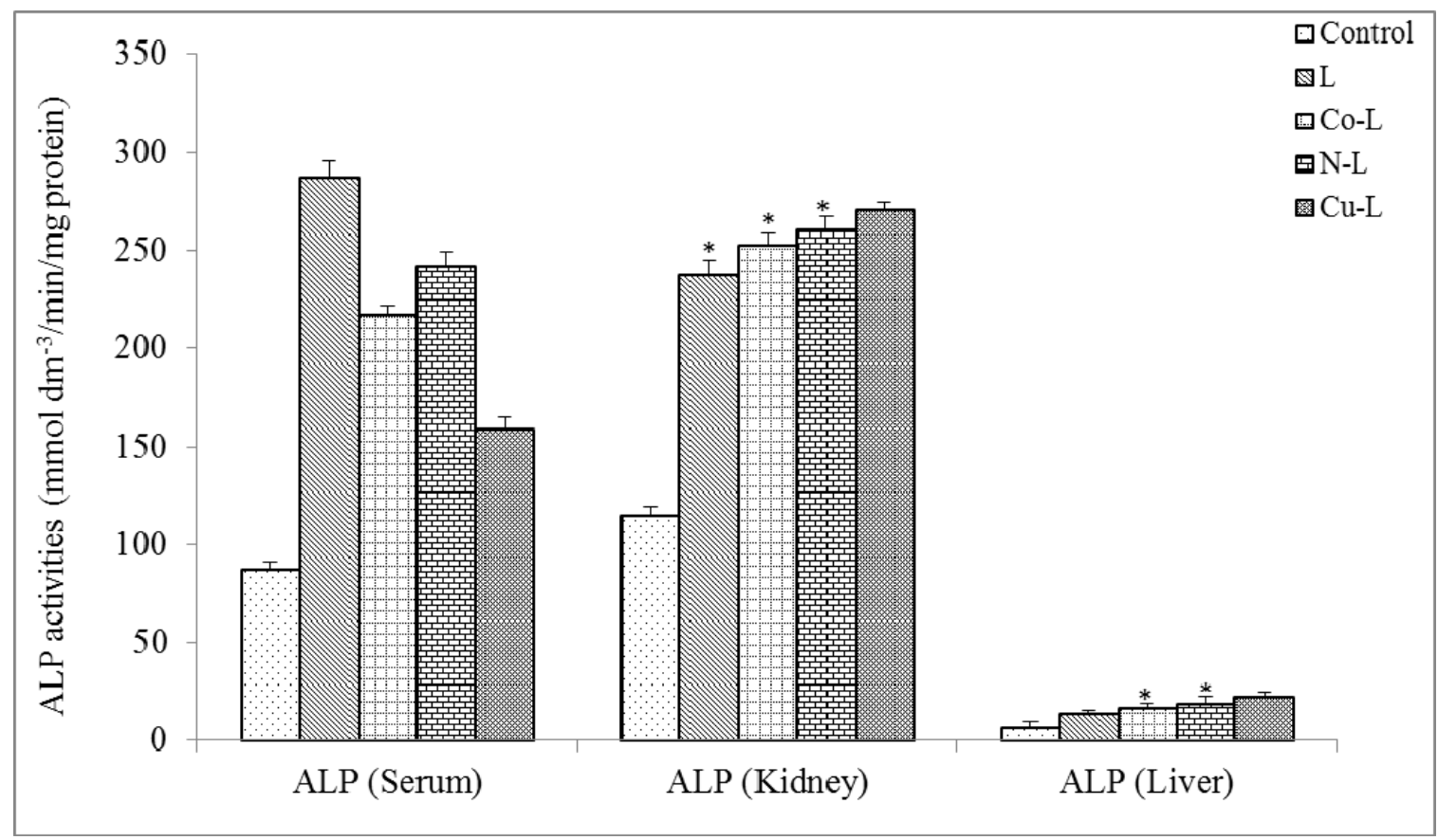

Figure 5. Effect of administration of ligand and the metal complex on the activities of alanine amino transferase (ALT) of rat serum, kidney and liver. * Significantly different from the control $(\mathrm{p}<0.05)$.

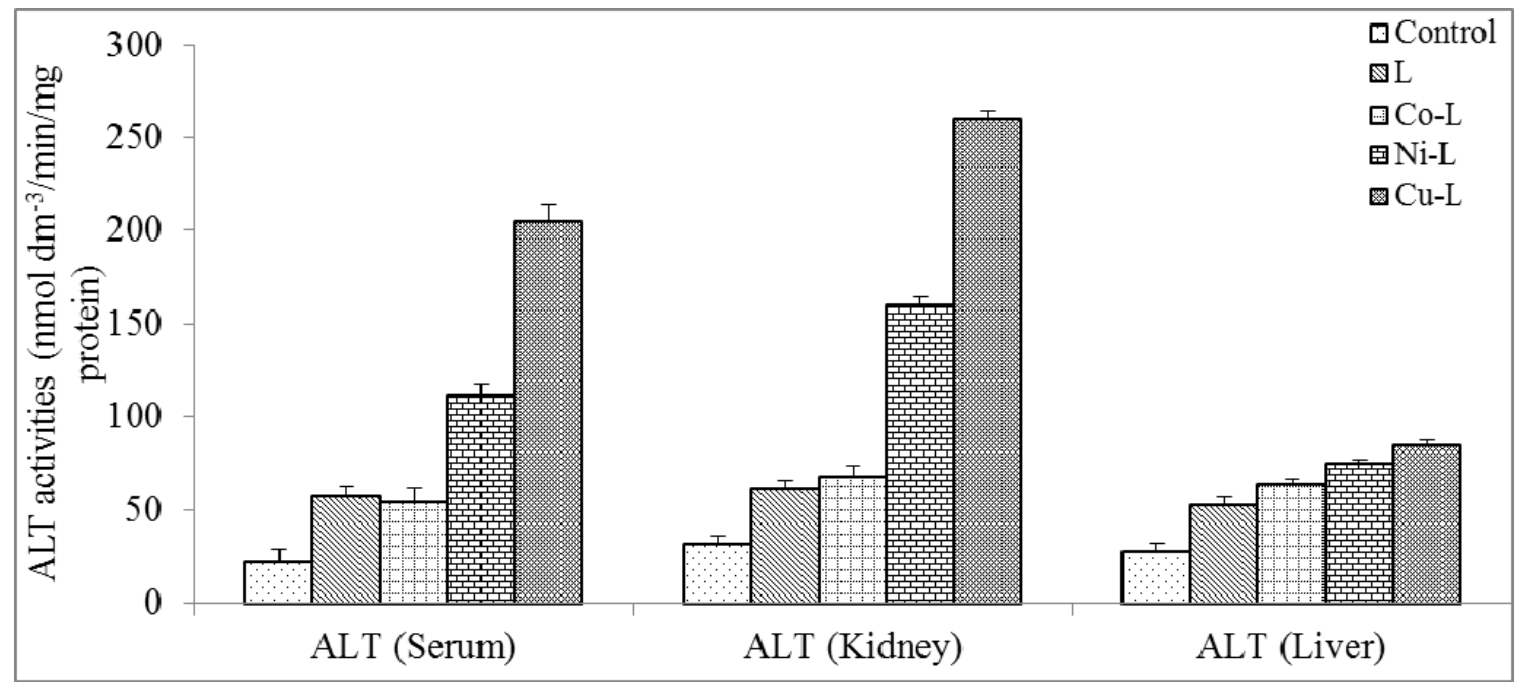


Figure 6. Effect of administration of ligand and the metal complex on the activities of aspartate amino transferase (AST) of rat serum, kidney and liver. * Significantly different from the control $(\mathrm{p}<0.05)$.

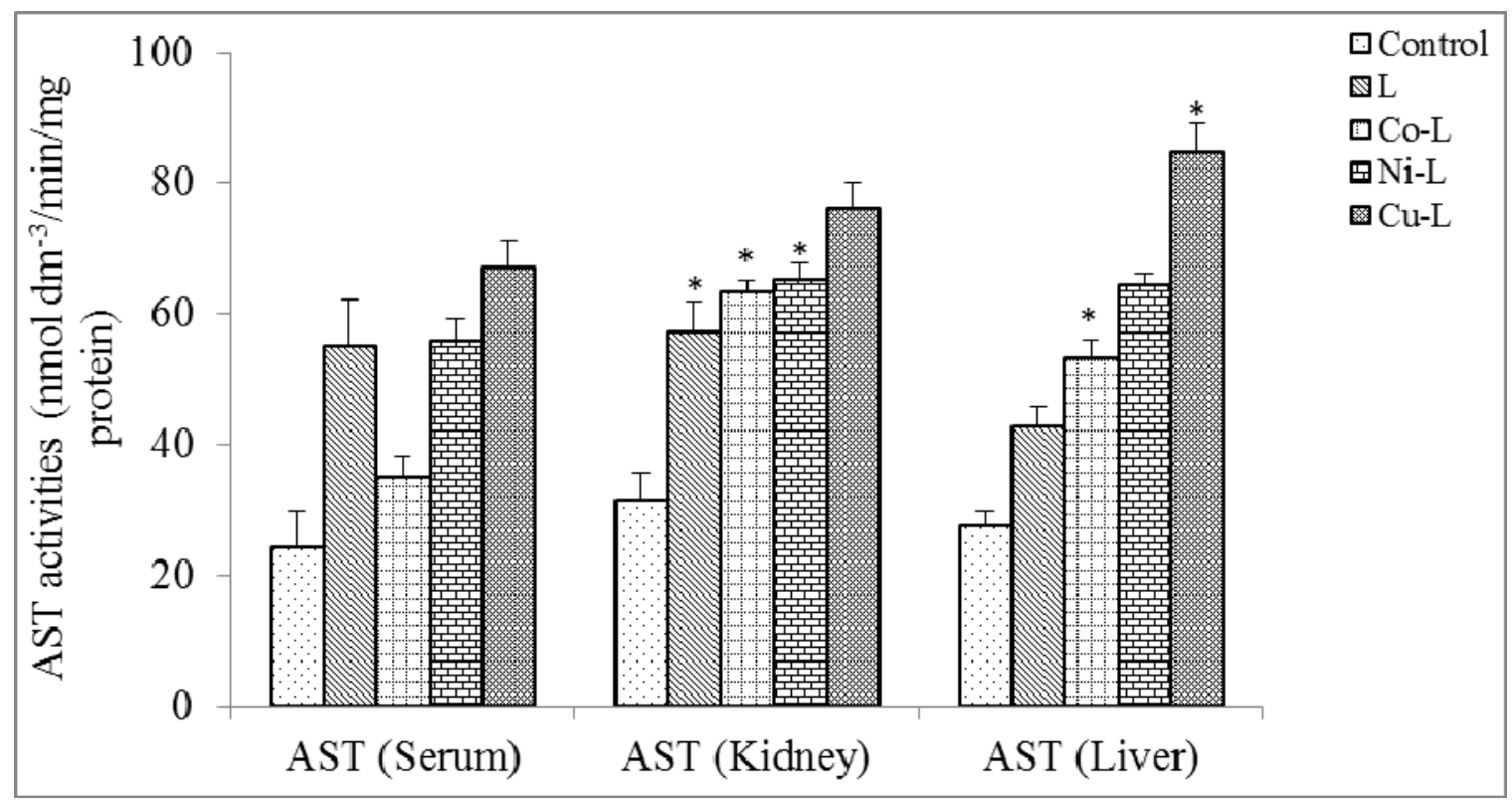

\section{Experimental}

\subsection{General}

All chemicals used in the preparation of the complexes and in solutions studies were of the highest purity available. Semicarbazide hydrochloride, potassium thiocyanate and 3\% hydrogen peroxide were supplied by Sigma. Co(II), Ni(II) chloride hexahydrate and $\mathrm{Cu}$ (II) chloride dihydrate (BDH) were used as received. The organic solvents used such as absolute ethanol and methanol were also obtained from BDH. Elemental analyses (C, H, N, S and Met) were performed at the Pontificia Universidade Catolica, Rio de Janeiro, Brazil. The analyses were repeated twice. The IR spectra were recorded from 4,000-400 $\mathrm{cm}^{-1}$ using a Perkin-Elmer SP3-30 FT-IR spectrometer. The spectra were recorded as KBr disks. The molar magnetic susceptibilities of the powdered samples were measured using a Faraday Balance Model 7650 with $\mathrm{Hg}\left[\mathrm{Co}(\mathrm{SCN})_{4}\right]$ as calibrant. The ultraviolet/visible analysis was carried out on a Genesys10S V1.200 spectrophotometer. The molar conductance measurements of the complexes were carried out in DMF using a Genway 4200 conductivity meter. Metal contents of the complexes were determined using an Alpha4 Atomic Absorption Spectrophotometer equipped with a PM8251 simple-pen recorder. Thin layer chromatography was carried out using TLC plates coated with silica gel. ALP, ALT, and AST assay kits were obtained from Randox Laboratories Limited (Antrim, United Kingdom). Clinical cultures of the micro-organism used were obtained from the University Teaching Hospital and the Department of Microbiology, University of Ilorin, Ilorin, Nigeria. Albino rats (Wistar strain) were obtained from the Department of Biochemistry, University of Ilorin, Ilorin, Nigeria. 


\subsection{Antimicrobial Screening}

The stimulatory or inhibitory activity of the ligand and the metal complexes synthesized were determined according to the procedure previously reported with slight modifications [14-16]. The bacterial species used for this test include clinical cultures of Escherichia coli, Staphylococcus aureus, Klebsiella species, Niesseria gonorrhoea, Salmonella typhi, Shigella species, Penicillium species, Pseudomonas aeruginosa and Aspergillus species. The antibacterial activities of the compounds were determined using sensitivity test, minimum inhibitory concentration and minimum bacterial concentration.

\subsection{Sensitivity Tests: Using Mueller Hinton Agar}

Plastic disposable sterile Petri dishes were used. Mueller Hinton agar $(20 \mathrm{~mL})$ was poured in and allowed to set. The plates were labelled, and then swabbed with the respective standardized test organism $(0.1 \mathrm{~mL})$. Holes $(8 \mathrm{~mm}$ diameter) were made using a cork borer. The holes were then filled with the test samples $(20 \mu \mathrm{g} / \mathrm{mL})$ and the control (solvent) and left to stand for $1 \mathrm{hr}$ for proper diffusion of the agent into the agar. The plates were kept in an incubator at $37^{\circ} \mathrm{C}$ and the zones of inhibition measured after 24 hrs. A plate containing only the agar was also kept in the incubator to determine whether contaminants were present.

\subsection{Sensitivity Disk Test}

Media plates of sensitivity test agar (STA) were prepared and inoculated from overnight slant cultures of the test organisms and spread as uniformly as possible throughout the entire media. The antimicrobial sample solution $(10 \mu \mathrm{g} / \mathrm{mL})$ impregnated disks were then placed on the inoculum media. These were incubated at $35{ }^{\circ} \mathrm{C}$ for $24 \mathrm{hrs}$. Degrees of sensitivity were determined by measuring visible areas of inhibition of growth using the zone reader.

\subsection{Antifungal Activity Test}

The plates were filled with the SDA agar (two-thirds) and the fungi specie inoculated into it and the sample solutions added as in the sensitivity test above.

\subsection{Determination of the Minimum Inhibitory Concentration (Bactericidal)}

To each of a series of sterile stoppered test tubes, a standard volume of medium that supports the growth of the test organism was added; this was followed by the addition of $0.1 \mathrm{~mL}$ to $7.0 \mathrm{~mL}$ at an interval value of $0.05 \mathrm{~mL}$ of each of the antimicrobial metal complexes and ligand solutions representing $10,15,20,25,30,35,40,45,50,80,100,200,300,400,500,600,700 \mu \mathrm{g} / \mathrm{mL}$, respectively, in a final mixture of $10 \mathrm{~mL}$. Standard volume of the inoculum $(0.2 \mathrm{~mL})$ of each of the test, one in which the test sample (antimicrobial) was omitted and the other in which the test organism was omitted. All the tubes were incubated at $35{ }^{\circ} \mathrm{C}$ for $24 \mathrm{hrs}$. All tubes that show turbidity (evidence of growth) were removed while those showing no turbidity were subcultured into nutrient broth by transferring a loopful of the culture which have been properly shaken into $10 \mathrm{~mL}$ of the broth and 
incubated for $8 \mathrm{hrs}$ at $35^{\circ} \mathrm{C}$. This broth culture was further subcultured on to nutrient agar media by a single stroke streaking and incubated at $35^{\circ} \mathrm{C}$ for $24 \mathrm{hrs}$. The plates were observed for growth after the period of incubation. The minimum concentration plates showing no growth after this period represents the minimum bacterial concentration (MBC).

\subsection{Treatment of Animals}

Male albino rats (Wistar strain), weighing between 160-180 g were obtained commercially from Department of Biochemistry, University of Ilorin, Ilorin, Nigeria. They were kept in wire meshed cages and fed with commercial rat chow (Bendel Feeds Nigeria Ltd) and supply water ad libitum. Thirty six rats were divided into three groups of six rats per group. The first group was used as control and received distilled water. The second group of rats was treated with free ligand (2,5-diamino-1,3,4thiadiazole) while the third group were subdivided into three groups treated with metal complexes $\left[\mathrm{Cu}(\mathrm{L})_{2} \mathrm{Cl}_{2}\right],\left[\mathrm{Co}(\mathrm{L})_{2} \mathrm{Cl}_{2}\right]$ and $\left[\mathrm{Ni}(\mathrm{L})_{2} \mathrm{Cl}_{2}\right]$. The distilled water, ligand and solution of metal complex were administered orally to the rats of various groups two times daily for seven days at the dose of $0.60 \mathrm{mg} / \mathrm{Kg}$ body weight. The animals were sacrificed $24 \mathrm{hrs}$ after the last treatment.

\subsection{Preparation of Serum and Tissue Homogenates}

The method described by Yakubu et al. [17] was used to prepare the serum. The rats were sacrificed by cervical dislocation. Blood samples were collected by cardiac punctures into clean, dry centrifuge tube after which they were left for $10 \mathrm{~min}$ at room temperature. The tubes were then centrifuged for 10 min at 3,000 $\times \mathrm{g}$ in an MSC (Essex, UK) bench centrifuge. The clear supernatant (serum) was aspirated using a Pasteur pipette into clean, dry sample bottles and then frozen overnight before use.

The liver and kidney excised from rat, blotted of blood stains was rinsed in $1.15 \% \mathrm{KCl}$ and homogenized in four volumes of ice-cold $0.01 \mathrm{~mol} \mathrm{dm}^{-3}$ potassium phosphate buffer ( $\mathrm{pH} \mathrm{7.4).} \mathrm{The}$ homogenates were centrifuged at $12,500 \times \mathrm{g}$ for $15 \mathrm{~min}$ at $4{ }^{\circ} \mathrm{C}$ and the supernatants, termed the post-mitochondrial fractions (PMF) were aliquoted and used for enzyme assays.

\subsection{Determination of Serum and Tissue ALP, AST and ALT Activities}

Serum and tissue's ALP, AST and ALT activities were determined using Randox diagnostic kits. Determination of AST and ALT activities were based on the principle described by Relitman and Frankel [18]. ALP activity determination was based on the method of Wright et al. [19]. The yellow colour p-nitrophenol formed was monitored at $405 \mathrm{~nm}$. Protein determination of serum and all fractions was estimated by the method of Lowry et al. [20] as modified by Yakubu et al. [17] using bovine serum albumin as standard.

\subsection{Statistical Analysis}

The data were analyzed using one way ANOVA followed by Duncan multivariable post-hoc test for comparison between control and treated rats in all groups. Values of $p$ less than 0.05 were considered statistically significant. 


\subsection{Preparation of the 2,5-diamino-1,3,4-thiadiazole ligand $(\mathbf{L})$}

\subsubsection{Procedure}

Bithiourea $(30 \mathrm{~g}, 0.2 \mathrm{~mol})$ was introduced into a $250 \mathrm{~mL}$ round bottomed flask and $3 \% \mathrm{H}_{2} \mathrm{O}_{2}$ $(40 \mathrm{~mL})$ was added. The mixture was refluxed at $50-60{ }^{\circ} \mathrm{C}$ for $1 \mathrm{hr}$ with continuous stirring. The product was then filtered under vacuum and dried at $100^{\circ} \mathrm{C}$ in the oven and the percentage crude yield was determined. It was thereafter recrystallised from boiling water.

\subsubsection{Synthesis of the metal complexes}

The complex was prepared based on previous reported procedures with slight modifications [15]. An aqueous or ethanolic solution of the metal salt $\left(\mathrm{CuCl}_{2} \cdot 2 \mathrm{H}_{2} \mathrm{O}, \mathrm{CoCl}_{2} \cdot 6 \mathrm{H}_{2} \mathrm{O}\right.$ and $\left.\mathrm{NiCl}_{2} \cdot 6 \mathrm{H}_{2} \mathrm{O}\right)$ was mixed with an aqueous ethanolic solution of 2,5-diamino-1,3,4-thiadiazole (which was dissolved in minimum amount of the solvent; $0.01 \mathrm{~mol}$ each). The reaction mixture was heated in a $250 \mathrm{~mL}$ round bottomed flask for $15 \mathrm{~min}$ on a water bath and there was change of colouration, indicating the appearance of the precipitates of the complexes. The reaction mixture was reduced to about one third when the metal complex separated out on cooling. The complex formed was recovered from the solution by filtration. It was washed and recrystallised from ethanol and then dried in vacuum over $\mathrm{CaCl}_{2}$.

\section{Conclusions}

It is established from the combined results of the chemical and physical analysis and from previous reports that the ligand 2,5-diamino-1,3,4-thiadiazole (L) employed in this work coordinated with $\mathrm{Cu}$, $\mathrm{Co}$ and $\mathrm{Ni}$. The metal complexes possess better physical properties than the parent compound. Based on antimicrobial activities reported elsewhere and toxicological data from our experiments, metal complexes of 2,5-diamino-1,3,4-thiadiazole would be better therapeutic drugs for antibacterial treatment.

\section{Acknowledgement}

The authors appreciate the financial support of Science and Technology Education Post Basic (STEP B), University of Ilorin and Ajayi Crowther University, Oyo, Nigeria.

\section{References}

1. Samba, T.; Funahasi, Y.; Ono, N.; Yamamoto, Y.; Sagi, N.H.; Asada, M.; Yoshimatsu, K.; Wakabayashi, T. An Angiogenesis Inhibitor E7820 Shows Broad-spectrum Tumor Growth Inhibition in a Xenograft Model: Possible Value of Integrin $\alpha 2$ on Platelets as a Biological Marker. Clin. Cancer Res. 2004, 10, 1430-1438.

2. Slawinski, J.; Gdaniek, M. Synthesis, Molecular Structure, and in vitro Antitumor Activity of New 4-chloro-2-mercaptobenzenesulfonamide Derivatives. Eur. J. Med. Chem. 2005, 40, $377-389$. 
3. Chen, Q.; Rao, P.N.P.; Knaus, E.E. Design, Synthesis, and Biological Evaluation of N-acetyl-2-carboxybenzenesulfonamides: A Novel Class of Cyclooxygenase-2 (COX-2) Inhibitors. Bioorg. Med. Chem. 2005, 13, 2459-2468.

4. Gadad, A.K.; Noolvi, M.N.; Karpoormath, R.V. Synthesis and Anti-tubercular Activity of a Series of 2-sulfonamido/trifluoromethyl-6-substituted Imidazo[2,1-b]-1,3,4-thiadiazole Derivatives. Bioorg. Med. Chem. 2004, 12, 5651-5659.

5. Nieto, M.J.; Alovero, F.L.; Manzo, R.H.; Mazzieri, M.R. Benzenesulfonamide Analogs of Fluoroquinolones: Antibacterial Activity and QSAR Studies. Eur. J. Med. Chem. 2005, 40, 361-369.

6. Domínguez, J.N.; León, C.; Rodrigues, J.; de Domínguez, N.G.; Gut, J.; Rosenthal, P.J. Synthesis and Antimalarial Activity of Sulfonamide Chalcone Derivatives. Farmaco 2005, 60, 307-311.

7. Bult, A.; Sigel, H. Metal Ions in Biological Systems; Marcel Dekker: New York, NY, USA, 1983; Volume 116.

8. Casanova, J.; Alzuet, G.; Ferrer, S.; Borrás, J.; García-Granda, S.; Perez-Carreño, E. Metal Complexes of Sulfanilamide Derivatives Crystal Structure of $\left[\mathrm{Zn}(\text { sulfathiazole })_{2}\right] \cdot \mathrm{H}_{2} \mathrm{O}$. J. Inorg. Biochem. 1993, 51, 689-699.

9. Agrawal, O.P. Synthetic Organic Chemistry; Goel Publishing House: Merrut, India, 1985.

10. García-Raso, Á.; Fiol, J.J.; Rigo, S.; López-López, A.; Molins, E.; Espinosa, E.; Borrás, E.; Alzuet, G.; Borrás, J.; Castiñeiras, A. Coordination behaviour of sulfanilamide derivatives: Crystal structures of $\left.\left.[\mathrm{Hg} \text { (sulfamethoxypyridazinato })_{2}\right],[\mathrm{Cd} \text { (sulfadimidinato })_{2}\left(\mathrm{H}_{2} \mathrm{O}\right)\right] \cdot 2 \mathrm{H}_{2} \mathrm{O}$ and [Zn(sulfamethoxazolato $)_{2}$-(pyridine $)_{2}\left(\mathrm{H}_{2} \mathrm{O}\right)_{2}$ ]. Polyhedron 2000, 19, 991-1004.

11. Maurya, R.C.; Patel, P. Synthesis, Magnetic and Special Studies of Some Novel Metal Complexes of $\mathrm{Cu}(\mathrm{II}), \mathrm{Ni}(\mathrm{II}), \mathrm{Co}(\mathrm{II}), \mathrm{Zn}[\mathrm{II}), \mathrm{Nd}(\mathrm{III}), \mathrm{Th}(\mathrm{IV})$, and $\mathrm{UO}_{2}(\mathrm{VI})$ With Schiff Bases Derived from Sulfa Drugs, viz., Sulfanilamide/Sulfamerazine and o-vanillin. Spectrosc. Lett. 1999, 32, 213-236.

12. Gutierrez, L.; Alzuet, G.; Borrás, J.; Liu-González, M.; Sanz, F.; Castiñeiras, A. Influence of Tetrahedral Distortion of $\mathrm{CuN}_{4}$ Complexes on Spectroscopic Properties. Synthesis, characterization and crystal structures of $\left[\mathrm{Cu}\left(\mathrm{N}-(2-\text { methylpyridyl)benzenesulfonylamidate })_{2}\right]\right.$, $\left[\mathrm{Cu}(\mathrm{N}-(2-m e t h y l p y r i d y l) \text { Toluenesulfonylamidate })_{2}\right]$ and $[\mathrm{Cu}(\mathrm{N}-(2-m e t h y l p y r i d y l)$ naphthalenesulfonylamidate) $)_{2}$ ] Compounds. Polyhedron 2001, 20, 703-709.

13. Rameshkumar, N.; Veena, A.; Ilavarasan, R.; Adiraj, M.; Shanmugapandiyan, P.; Sridhar, S.K. Synthesis and Biological Activities of 2,6-Diaryl-3-methyl-4-piperidone Derivative. Biol. Pharm. Bull. 2003, 26, 188-193.

14. Obaleye, J.A.; Adediji, J.F.; Olayinka, E.T.; Adebayo, M.A. Synthesis, Antimicrobial Potential and Toxicological Activities of Ni(II) Complex of Mefloquine Hydrochloride. Res. Pharm. Biotech. 2009, 1, 9-15.

15. Adediji, J.F.; Olayinka, E.T.; Adebayo, M.A.; Babatunde, O. Antimalarial Mixed Ligand Metal Complexes: Synthesis, Physicochemical and Biological Activities. Int. J. Phys. Sci. 2009, 4, 529-534.

16. Mohamed, G.G.; Abdel-Wahab, Z.H. Mixed Ligand Complexes of Bis(phenylimine) Schiff Base Ligands Incorporating Pyridinium Moiety: Synthesis, Characterisation and Antibacterial Activitity. Spectrochim. Acta Part A Mol. Biomol. Spectrosc. 2005, 9, 2231-2238. 
17. Yakubu, M.T.; Akanji, M.A.; Oladiji, A.T. Aphrodisiac Potentials of Aqueous Extract of Fadogia Agrestis (Schweinf. Ex Heirn) Stem in Male Albino Rats. Asia J. Androl. 2005, 7, 399-404.

18. Relitman. S.; Frankel, S. A Colorimetric Method for the Detection of Serum Glutamic Oxalacetic and Glutamic Pyruvic Transaminases. Am. J. Chem. Path. 1957, 28, 56-63.

19. Wright, P.J.; Plummer, D.T.; Leathwood, P.T. Enzyme in Rat Urine Alkaline Phosphatase. Enzymologia 1972, 42, 317-327.

20. Lowry, O.H.; Rosebrough, N.J.; Farr, A.L.; Randall, R.J. Protein Measurement with Folin Phenol Reagent. J. Biol. Chem. 1951, 193, 265-275.

21. Obaleye, J.A.; Balogun, E.A.; Adeyemi, O.G. Synthesis and in vitro Effect of Some Metal-drug Complexes on Malaria Parasite. Biokemistri 1999, 9, 23-27.

22. Obaleye, J.A.; Nde-aga, J.B.; Balogun, E.A. Some Antimalaria Drug Metal Complexes: Synthesis, Characterization and Their in-vivo Evaluation against Malaria Parasite. Afr. J. Sci. 1997, 1, 10-12.

23. Moustafa, M.M. Spectrophotometric Analysis, Thermal Analysis and Gravimetric Determination of Some Metal Ions with Oxime and Schiff's Base Derivatives of N-furoylphenylhydroxylamine. J. Therm. Anal. Cal. 1997, 463-471.

24. Kapahi, A.; Pandeya, K.B.; Singh, R.P. Oxovanadium(IV) Complexes of Some Ortho-hydroxy Ketoximes. J. Inorgan. Nucl. Chem. 1976, 38, 2121-2122.

25. Cotton, F.A.; Wikinson, G.; Murillo, C.A.; Bochmann, M. Advanced Inorganic Chemistry, 6th ed.; Wiley: New York, NY, USA, 1999.

26. Reddy, P.S.; Reddy, K.H. Transition Metal Complexes of Benzil- $\alpha$-monoxime (BMO); X-ray Structure Determination of Co(BMO) $)_{3}$. Polyhedron 2000, 19, 1687-1692.

27. Reese, R.E.; Belts, R.F. Handbook of Antibiotics, 2nd ed.; Little Brown and Company: New York, NY, USA, 1993.

28. Akanji, M.A.; Olagoke, O.A.; Oloyede, O.B. Effects of Chronic Consumption of Metabisulphate on the Integrity of the Rat Kidney Cellular System. Toxicology 1993, 81, 173-179.

29. Malomo, S.O.; Ale, O.O.; Adedoyin, A.M. Effect of Chloroquine on Some Leukocyte Enzymes During Protein Energy Malnutrition - an in vitro study. Biosci. Res. Commun. 1993, 5, 53-55.

30. Macfarlane, I.; Bomford, A.; Sherwood, R.A. Liver Diseases and Laboratory Medicine; ACB Ventures Publications: London, UK, 2000.

31. Halworth, M.; Capps, N. Therapeutic Drugs Monitoring and Clinical Biochemistry; ACB Ventures Publications: London, UK, 1993.

Sample Availability: Samples of the compounds $\mathrm{Co}(\mathrm{L})_{2} \mathrm{Cl}_{2}, \mathrm{Ni}(\mathrm{L})_{2} \mathrm{Cl}_{2}$ and $\mathrm{Cu}(\mathrm{L})_{2} \mathrm{Cl}_{2}$ are available from the authors.

(C) 2011 by the authors; licensee MDPI, Basel, Switzerland. This article is an open access article distributed under the terms and conditions of the Creative Commons Attribution license (http://creativecommons.org/licenses/by/3.0/). 